\title{
You Can't Get There from Here: Discovering Where to Begin a Practice-led Inquiry - Notes and Reflections from Thailand.
}

\author{
Keywords \\ Topic, Starting Point, Concerns, Ways of knowing, Line of Inquiry.
}

In Thailand, it is common for art and design students to select a research topic prior to beginning their Masters studies. On the basis of this choice, students are - if accepted - then expected to research, produce and defend a substantial body of creative work about their topic. Underlying this approach is an assumption that topic selection is a relatively unproblematic moment in the development of a creative project. In this study I argue that the opposite is the case and that investing time, energy and resources in helping students to discover a relevant, meaningful and original topic - rather than conjure one from thin air or fall back on habitual approaches to creative practice - lays the foundations for relevance, meaning and originality in the project itself. This is, I believe, true of all summative postgraduate projects in art and design but is particularly so in practice-led inquiries where greater weight is necessarily given to producing insight into the complex and often troubled relations between creative practice and knowledge production. Our MfA in Visual Communication addresses this issue through a one semester period of intensive intellectual and practical labour that precedes topic selection. At the heart of this is a series of studio exercises that set up and structure critical and material encounters between research and practice. We begin with critical reflection on the things that matter to the student within and beyond their practice - their 'concerns'. Drafting and crafting concerns is, surprisingly for many, a difficult and sometimes troubling task. Yet when done well it produces a delicate linguistic and conceptual tissue that connects the personal, the social and the professional and, in so doing, establishes a field of ideas within which points of departure for meaningful practice-led inquiry might begin to disclose themselves. With a small set of working concerns in hand, we invite students to develop two cross-fertilizing lines of inquiry. Transforming concerns into questions, invites discussion of a variety of forms and means of answer seeking and through this consideration of different epistemological and methodological traditions or ways of knowing. Likewise, asking 'who else seeks answers to these questions', invites the identification of theorists and practitioners who might figure in the conceptual apparatus that will frame inquiry. Above all, responding to concerns and questions through experimental creative production, invites students to confront the implications of reimagining their creative practices as forms of inquiry and, in particular to engage directly with a problematique at the heart of practice-led approaches to research: that is, the relative epistemological status of linguistic (propositional) and material (affective-aesthetic) operations - the relations between words and works. These activities serve to nurture meaningful research topics and directions of inquiry that are grounded in engagement with fundamental ideas and processes central to practice-led and practice-based research. I illustrate this approach by discussing two student responses to and reflections on working towards a starting point in this way. 